\title{
PERBANDINGAN COMPLETE RESPONSE PENDERITA KANKER OVARIUM STADIUM LANJUT YANG MENDAPAT REJIMEN PACLITAXEL-CARBOPLATIN DENGAN REJIMEN CYCLOPHOSPHAMIDE-ADRIAMYCIN-CISPLATIN SEBAGAI KEMOTERAPI LINI PERTAMA
}

\author{
M. Sibuea ${ }^{1}$, M. Lutfi ${ }^{2}$, M. Hakimi
}

\begin{abstract}
Background: Introduction of Platinum and Paclitaxel has increased survival rate in advanced epithelial ovarian cancer. Several studies have been tried to establish the better combination with those anticancer drugs.

Objectives: Comparing complete response (CR) and progression-free survival (PFS) between PaclitaxelCarboplatin and CAP as a first line treatment in advanced epithelial ovarian cancer.

Method: This research used cohort retrospective study. Fifthy-three subjects with epithelial ovarian cancer FIGO stage III and IV were collected from Dr.Sardjito Hospital's medical record analysis between January 2009 and December 2013, and divided into two groups according to chemotherapy regimens. Complete response and progression-free survival were determined after cytoreductive surgery and total 6 courses of chemotherapy.
\end{abstract}

Result and Discussion: The frequency of complete response was similar, 61,5\% in Paclitaxel Carboplatin group as compared with $63 \%$ in CAP group ( $R R 0,977,95 \% \mathrm{Cl} 0,642-1,487, p=1,000$ ). Kaplan-Meier curves showed no difference in progression-free survival between the groups, with median PFS was 15 months (95\% Cl 13,228-16,772) on Paclitaxel-Carboplatin and 14 months on CAP $(95 \% \mathrm{Cl} 7,686-20,314)$ ( $p$ logrank $=0,741)$. Patients undergo optimal cytoreductive surgery attained more complete response $(O R 8,274$, $95 \% \mathrm{Cl} 1,775-38,559, \mathrm{p}=0,007)$ and had a longer PFS than the suboptimal group (17 vs 13 months, $\mathrm{p}$ logrank=0,046).

Conclusion: Paclitaxel-Carboplatin was not superior compared with CAP regimen as first line chemotherapy in advanced epithelial ovarian cancer. Further evaluation of survival, toxicity profile, and quality of life were needed to determine superiority of Paclitaxel-Carboplatin compared with CAP. Optimal cytoreductive surgery was an independent predictor for a better prognosis.

Keywords: advanced ovarian cancer, chemotherapy, Paclitaxel-Carboplatin, CAP

\begin{abstract}
ABSTRAK
Latar belakang: Survival rate penderita kanker ovarium epitelial stadium lanjut meningkat sejak diperkenalkannya Platinum dan Paclitaxel. Beberapa penelitian telah berusaha untuk menentukan kombinasi yang lebih baik dari obat-obatan tersebut.

Tujuan: Membandingkan complete response (CR) dan progression-free survival (PFS) antara PaclitaxelCarboplatin dengan CAP sebagai terapi lini pertama pada kanker ovarium epitelial stadium lanjut.

Metode: Penelitian ini menggunakan studi cohort retrospective. Lima puluh tiga subyek dengan kanker ovarium epitelial stadium III-IV (FIGO) didapatkan dari analisis rekam medis RSUP Dr. Sardjito mulai Januari 2009 hingga Desember 2013, yang terbagi menjadi dua kelompok berdasarkan jenis kemoterapi yang
\end{abstract}

1,2,3 Bagian Obstetri dan Ginekologi FK UGM/RSUP Dr. Sardjito Yogyakarta 
diterima. Complete response dan PFS ditentukan setelah pasien menjalani operasi sitoreduksi dan total 6 siklus kemoterapi.

Hasil dan Pembahasan: Frekuensi CR kelompok Paclitaxel Carboplatin $(61,4 \%)$ serupa dengan kelompok CAP (63\%) (RR 0,977, 95\% Cl 0,642-1,487, p=1,000). Kurva Kaplan-Meier tidak menunjukkan perbedaan PFS di antara kedua kelompok, dengan median PFS Paclitaxel-Carboplatin 15 bulan (95\% Cl 13,228-16,772) dan CAP 14 bulan (95\% Cl 7,686-20,314) (p log-rank=0,741). Pasien dengan operasi sitoreduksi optimal mencapai CR lebih banyak (OR 8,274, 95\% Cl 1,775-38,559, $\mathrm{p}=0,007$ ) dan median PFS lebih panjang dibandingkan dengan kelompok suboptimal (17 vs 13 bulan, p log-rank=0,046).

Kesimpulan: Paclitaxel-Carboplatin tidak lebih superior dibandingkan dengan CAP sebagai kemoterapi lini pertama pada kanker ovarium epitelial stadium lanjut. Namun, masih diperlukan pengukuran survival, profil toksisitas, dan kualitas hidup guna menentukan keunggulan rejimen Paclitaxel-Carboplatin dibandingkan dengan CAP. Operasi sitoreduksi yang optimal merupakan prediktor independen dari prognosis yang lebih baik.

Kata kunci: kanker ovarium stadium lanjut, kemoterapi, Paclitaxel-Carboplatin, CAP

\section{PENDAHULUAN}

Kurang lebih $90 \%$ kanker ovarium merupakan jaringan kanker yang berasal dari epitel selomik atau mesotelium. Oleh karena penyakit ini umumnya bersifat asimtomatik hingga terjadi metastasis, maka lebih dari duapertiganya terdiagnosis pada stadium lanjut (stadium III dan IV) sehingga menjadi keganasan paling mematikan dari traktus genitalia perempuan. Pembedahan sitoreduktif yang agresif dan kemoterapi dilakukan sebagai usaha untuk memperbaiki survival rate pasien dengan kanker ovarium epitelial. Namun, oleh karena pembedahan yang bersifat kuratif dan reseksi komplet seringkali tidak tercapai, maka kemoterapi menjadi senjata lain dalam terapi kanker ovarium stadium lanjut. ${ }^{1,2}$

Setelah dilakukan pembedahan sitoreduktif, kanker ovarium epitelial stadium lanjut umumnya bersifat sensitif terhadap kemoterapi dengan response rate lebih dari $80 \%$ terhadap terapi berbasis platinum. ${ }^{2,3}$ Terdapat beberapa kombinasi obat dengan komponen berbasis platinum yang digunakan dalam kemoterapi kanker ovarium epitelial stadium lanjut dan beberapa penelitian telah mencoba untuk membuktikan kombinasi obat yang lebih baik..
Salah satunya adalah rejimen CAP yang merupakan kombinasi Cyclophosphamide-Adriamycin-Cisplatin, yang efektif dalam meningkatkan overall response dan survival rate pada pasien yang belum pernah mendapat pengobatan. ${ }^{4}$ Pada awal tahun 1990-an, untuk pertama kalinya Paclitaxel diujicobakan pada kasus kanker ovarium. Penelitian yang dilakukan oleh Gynecologic Oncology Group (GOG) \#111, yang didukung oleh penelitian European-Canadian Intergroup (OV10), menunjukkan bahwa rejimen Cisplatin-Paclitaxel lebih superior jika dibandingkan dengan kontrol berbasis platinum dalam hal response rate, median progression-free survival, dan overall survival. ${ }^{5}$ The International Collaborative Ovarian Neoplasm Study (ICON)3 adalah penelitian pertama dan satu-satunya yang membandingkan Paclitaxel-Carboplatin dengan kontrol berbasis platinum (non-Taxane) dan Carboplatin tunggal. Penelitian tersebut menunjukkan bahwa Carboplatin tunggal dan CAP sama efektifnya dengan Paclitaxel-Carboplatin sebagai kemoterapi lini pertama pada penderita kanker ovarium. ${ }^{6}$

Oleh karena itu, penelitian ini berusaha untuk membandingkan pengaruh rejimen yang dipakai di RSUP Dr.Sardjito, yaitu PaclitaxelCarboplatin dengan CAP, terhadap complete 
response dan progression-free survival penderita kanker ovarium epitelial stadium lanjut, sehingga nantinya dapat dijadikan pertimbangan untuk menentukan kemoterapi lini pertama pada kelompok penderita tersebut.

\section{METODE}

Penelitian ini bersifat kohort retrospektif dengan mengambil data dari rekam medik RSUP Dr. Sardjito Yogyakarta sejak 1 Januari 2009 sampai dengan 31 Desember 2013. Subyek penelitian adalah penderita kanker ovarium dengan kriteria inklusi sebagai berikut: telah menjalani surgical staging dengan hasil kanker ovarium stadium IIIIV menurut kriteria FIGO, menjalani pembedahan sitoreduktif dan kemoterapi ajuvan di RSUP Dr.Sardjito, hasil pemeriksaan histologi massa tumor menunjukkan keganasan epitelial, serta menjalani pemeriksaan klinis, radiologis, dan CA-125 sesudah kemoterapi. Pasien dieksklusi apabila: tidak menyelesaikan kemoterapi sebanyak 1 seri (6 siklus), hasil pemeriksaan histologi massa tumor menunjukkan keganasan epitelial tipe borderline (low malignant potential), didapatkan keganasan lain di samping kanker ovarium, atau pernah menjalani kemoterapi dan atau radiasi untuk kanker ovarium atau keganasan lain sebelumnya.

Variabel tergantung yang akan dievaluasi adalah complete response dan progression-free survival. Complete response adalah hilangnya semua bukti dari keberadaan penyakit pada 2 kali observasi dengan selang waktu tidak kurang dari 4 minggu, yang dinilai setelah penderita kanker ovarium menyelesaikan kemoterapi 1 seri (6 siklus). Bukti tersebut meliputi klinis, laboratoris, dan radiologis. Bukti klinis meliputi tidak adanya keluhan (simtom) yang berkaitan dengan kanker ovarium dan hasil pemeriksaan fisik yang normal pada pemeriksaan palpasi abdomen dan bimanual. Bukti laboratoris adalah nilai CA-125 $<35 \mathrm{U} / \mathrm{mL}$. Bukti radiologis adalah tidak ditemukannya massa baru, asites, atau gambaran metastasis pada pemeriksaan USG (transabdominal dan/atau transvaginal), CTscan abdomen, dan/atau foto dada. Rekurensi ditegakkan berdasarkan munculnya massa baru atau metastasis pada pemeriksaan fisik maupun imaging atau penilaian kadar CA-125, dengan kriteria sebagai berikut: a) pada pasien dengan nilai CA-125 yang meningkat sebelum terapi kemudian kembali ke nilai normal, maka harus terdapat bukti bahwa nilai CA-125 meningkat $\geq 2$ kali nilai referensi normal ( $\geq 70 \mathrm{U} / \mathrm{mL}$ ) pada 2 kali pengukuran dengan selang waktu 1 minggu, b) pada pasien dengan nilai CA-125 yang meningkat sebelum terapi namun tidak pernah kembali ke nilai normal, maka harus terdapat bukti bahwa nilai CA-125 meningkat $\geq 2$ kali nilai terendah yang pernah dicapai, pada 2 kali pengukuran dengan selang waktu 1 minggu, c) pada pasien dengan nilai CA-125 yang normal sebelum terapi, maka harus terdapat bukti bahwa nilai CA-125 meningkat $\geq 2$ kali nilai referensi normal ( $\geq 70 \mathrm{U}$ / $\mathrm{mL}$ ) pada 2 kali pengukuran dengan selang waktu 1 minggu. Progression-free survival dicatat sebagai waktu pertama kali ditemukannya tandatanda rekurensi. Sementara itu variabel luar yang mungkin berpengaruh terhadap tercapainya complete response dan progression-free survival meliputi umur penderita, stadium penyakit, jenis operasi sitoreduktif, dan tipe histologi.

Analisis univariat, bivariat dan multivariat digunakan dalam penelitian ini. Uji chi-square digunakan untuk mengetahui hubungan antara dua variabel. Analisis survival KaplanMeier dengan log-rank test digunakan untuk mengetahui hubungan jenis kemoterapi yang digunakan dengan progression-free survival yang dicapai. Analisis multivariat dengan analisis survival (Cox's regression) digunakan untuk mengetahui hubungan semua variabel terhadap variabel tergantung (progression-free survival). 


\section{HASIL DAN PEMBAHASAN}

Dalam penelitian ini didapatkan 53 subyek penelitian, yang dibagi menjadi 2 kelompok yaitu kelompok yang mendapat rejimen PaclitaxelCarboplatin ( $n=26)$ dan CAP ( $n=27)$. Median usia pada kelompok Paclitaxel-Carboplatin adalah 51 tahun sementara pada kelompok CAP adalah 52 tahun, dimana proporsi penderita yang berusia $<50$ tahun pada kelompok CAP lebih banyak (63\%) daripada kelompok Paclitaxel-Carboplatin (46,2\%). Pada kedua kelompok tipe histologi yang paling banyak ditemukan adalah tipe musinosumclear cell, dimana mayoritas dijumpai penderita kanker ovarium epitelial stadium III (kelompok Paclitaxel-Carboplatin 92,3\% dan kelompok CAP $74,1 \%$ ) dan lebih banyak penderita yang menjalani operasi sitoreduksi optimal (kelompok Paclitaxel-Carboplatin 53,8\% dan kelompok CAP 63\%) (Tabel 1).

TABEL 1. Karakteristik subyek penelitian

\begin{tabular}{|c|c|c|}
\hline Variabel & $\begin{array}{c}\text { Paclitaxel- } \\
\text { Carboplatin } \\
(n=26)\end{array}$ & $\begin{array}{l}\text { CAP } \\
(n=27)\end{array}$ \\
\hline \multicolumn{3}{|l|}{ Umur (tahun) } \\
\hline Median (interval) & $51(36-66)$ & $52(37-66)$ \\
\hline$<50$ tahun & $12(46,2)$ & $17(63)$ \\
\hline$\geq 50$ tahun & $14(53,8)$ & $10(37)$ \\
\hline \multicolumn{3}{|l|}{ Stadium (\%) } \\
\hline III & $24(92,3)$ & $20(74,1)$ \\
\hline IV & $2(7,7)$ & $7 \quad(25,9)$ \\
\hline \multicolumn{3}{|l|}{ Tipe histologi (\%) } \\
\hline $\begin{array}{l}\text { Serosum- } \\
\text { Endometrioid }\end{array}$ & $5(19,2)$ & $6(22,2)$ \\
\hline $\begin{array}{l}\text { Musinosum-Clear } \\
\text { cell }\end{array}$ & $11(42,3)$ & $11(40,7)$ \\
\hline Lain-lain & $10(38,5)$ & $10(37)$ \\
\hline \multicolumn{3}{|l|}{ Jenis operasi (\%) } \\
\hline Optimal & $14(53,8)$ & $17(63,0)$ \\
\hline Suboptimal & $12(46,2)$ & $10(37,0)$ \\
\hline
\end{tabular}

Complete response yang dicapai kelompok Paclitaxel-Carboplatin sebesar 61,5\% (16 dari 26 subyek) sementara kelompok CAP adalah 63\% (17 dari 27 subyek). Dari analisis Chi-square antara variabel bebas (Pacitaxel-Carboplatin/ CAP) dengan variabel tergantung (complete response) didapatkan nilai $\chi^{2}=.000$ dengan nilai $p=1,000, R R=0,977$ (95\% Cl 0,642-1,487). Hal ini menunjukkan tidak terdapat perbedaan antara kedua kelompok rejimen dalam hal complete response yang dicapai pasca-operasi sitoreduktif yang diikuti dengan kemoterapi 1 seri (6 siklus). Tabel 2 menunjukkan analisis bivariat antara variabel luar dengan complete response yang dicapai, dimana variabel stadium dan jenis operasi sitoreduksi memiliki hubungan yang bermakna secara statistik maupun klinis dengan complete response yang dicapai $(\mathrm{p}<0,05$ dan $R R>2$ ). Sementara dalam analisis multivariat tampak bahwa jenis operasi sitoreduksi adalah satu-satunya faktor luar yang mempengaruhi variabel bebas dan variabel tergantung, yang bermakna baik secara statistik maupun klinis (RR 8,274 $p=0,007,95 \% \mathrm{Cl}$ 1,775-38,559) (Tabel 3).

Progression-free survival (PFS) dihitung sejak dilakukannya operasi hingga didapatkan tanda-tanda rekurensi yang pertama kali. Analisis dilakukan dengan metode KaplanMeier menggunakan SPSS untuk Windows versi 16.0, dimana nilai $\mathrm{p}$ dihitung dengan log-rank test untuk mengetahui signifikansinya. Tampak bahwa median progression-free survival pada kelompok Paclitaxel-Carboplatin tidak berbeda bermakna dengan kelompok CAP (log-rank $p=0,741$, PFS Pacitaxel-Carboplatin 15 bulan, 95\% $\mathrm{Cl} 13,228-16,772$ dan PFS CAP 14 bulan, 95\% Cl 7,686-20,314) (Gambar 1). Dalam uji bivariat menggunakan log-rank test terhadap variabel luar dan progression-free survival didapatkan jenis operasi sitoreduksi sebagai satu-satunya faktor independen yang secara bermakna mempengaruhi progression-free survival ( $p$ log- 
rank=0,046), dimana kelompok pasien yang menjalani operasi sitoreduksi optimal memiliki PFS yang lebih panjang (17 bulan) dibandingkan dengan kelompok suboptimal (13 bulan).

Keefektifan dari berbagai obat kemoterapi diukur dengan response rate (complete response dan partial response), angka negative secondlook, progression-free survival (PFS), dan overall survival (OS). ${ }^{7}$ Penambahan Paclitaxel (golongan Taxane) pada rejimen berbasis platinum sejak tahun 1990-an sebagai kemoterapi lini pertama kanker ovarium epitelial stadium lanjut telah menunjukkan peningkatan response rate (termasuk di dalamnya complete response), durasi progression-free survival, dan overall survival. ${ }^{8}$

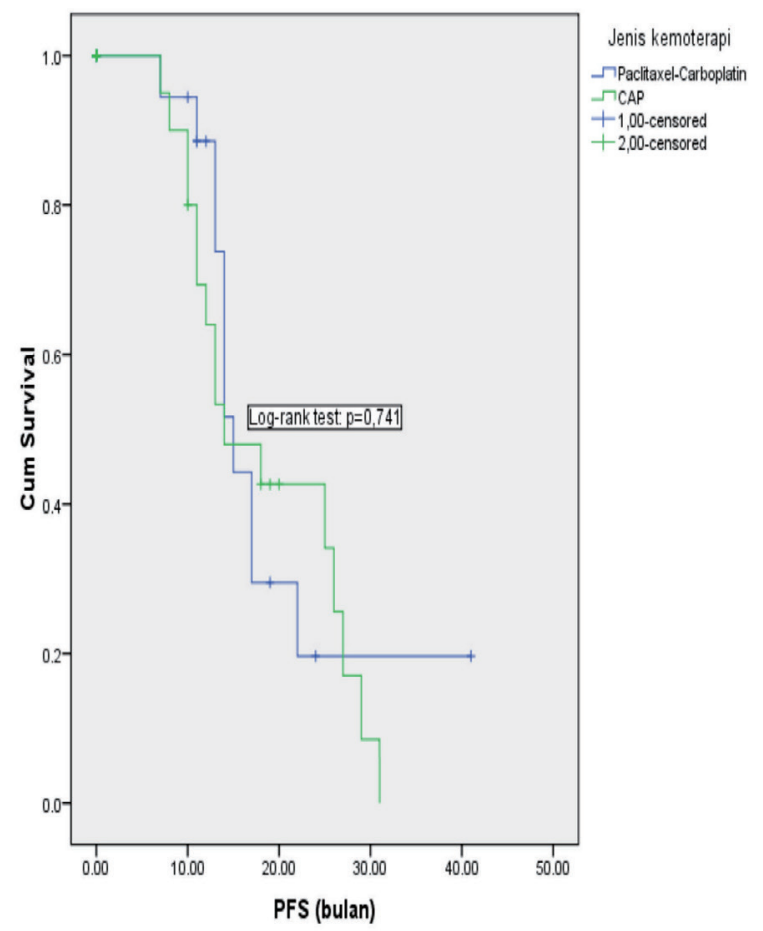

GAMBAR 1. Kurva Kaplan-Meier progression-free survival penderita kanker ovarium epitelial stadium lanjut berdasarkan jenis kemoterapi (PaclitaxelCarboplatin-CAP)

TABEL 2. Analisis bivariat (Chi-square) antara variable luar dengan variabel tergantung (complete response)

\begin{tabular}{|c|c|c|c|c|c|c|c|}
\hline \multirow{2}{*}{ Variabel } & \multicolumn{2}{|r|}{ CR (+) } & \multicolumn{2}{|c|}{ CR (-) } & \multirow{2}{*}{$R R$} & \multirow{2}{*}{$95 \% \mathrm{Cl}$} & \multirow{2}{*}{$p$} \\
\hline & $n$ & $\%$ & $n$ & $\%$ & & & \\
\hline \multicolumn{8}{|l|}{ Umur (tahun) } \\
\hline$<50$ tahun & 16 & 55,2 & 13 & 44,8 & 0,779 & $0,514-1,181$ & 0,376 \\
\hline$\geq 50$ tahun & 17 & 70,8 & 7 & 29,2 & 1 & & \\
\hline \multicolumn{8}{|l|}{ Stadium (\%) } \\
\hline III & 31 & 70,5 & 13 & 29,5 & 3,170 & $1,369-7,339$ & $0,019 *$ \\
\hline IV & 2 & 22,2 & 7 & 77,8 & 1 & & \\
\hline \multicolumn{8}{|l|}{ Tipe histologi (\%) } \\
\hline $\begin{array}{l}\text { Serosum- } \\
\text { Endometrioid }\end{array}$ & 6 & 54,5 & 5 & 45,5 & 0,992 & $0,508-1,937$ & 1,000 \\
\hline Musinosum-Clear cell & 16 & 72,7 & 6 & 27,3 & 1,322 & $0,825-2,120$ & 0,382 \\
\hline Lain-lain & 11 & 55 & 9 & 45 & 1 & & \\
\hline \multicolumn{8}{|l|}{$\begin{array}{l}\text { Operasi } \\
\text { sitoreduksi(\%) }\end{array}$} \\
\hline Optimal & 26 & 83,9 & 5 & 16,1 & 2,636 & $1,403-4,954$ & $.000 *$ \\
\hline Suboptimal & 7 & 31,8 & 15 & 68,2 & 1 & & \\
\hline
\end{tabular}

Keterangan: ${ }^{*}$ bermakna $(p<0,05)$ 
TABEL 3. Analisis pengaruh faktor luar terhadap variabel bebas (PaclitaxelCarboplatin/CAP) dan variabel tergantung (complete response)

\begin{tabular}{lccc}
\hline & OR & $95 \%$ CI & $p$ \\
\hline $\begin{array}{l}\text { Jenis kemoterapi } \\
\text { - Paclitaxel Carboplatin CAP }\end{array}$ & 0,983 & $0,233-4,144$ & 0,981 \\
\hline $\begin{array}{l}\text {-Stadium } \\
\quad \text { III }\end{array}$ & 2,209 & $0,275-17,737$ & 0,456 \\
$\quad$ IV & & & \\
\hline $\begin{array}{l}\text { Operasi sitoreduksi } \\
\text { Optimal } \\
\text { Suboptimal }\end{array}$ & 8,274 & $1,775-38,559$ & $0,007^{*}$ \\
\hline
\end{tabular}

Keterangan: *bermakna $(p<0,05)$

TABEL 4. Log Rank Test antara variabel luar dengan progression-free survival

\begin{tabular}{|c|c|c|c|}
\hline Variable & $\begin{array}{l}\text { Median PFS } \\
\text { (bulan) }\end{array}$ & $x^{2}$ & $p$ \\
\hline \multicolumn{4}{|l|}{ Umur } \\
\hline$<50$ tahun & 14 & 0,847 & 0,357 \\
\hline$\geq 50$ tahun & 15 & & \\
\hline \multicolumn{4}{|l|}{ Stadium } \\
\hline III & 15 & 0,682 & 0,409 \\
\hline IV & 11 & & \\
\hline \multicolumn{4}{|l|}{ Tipe histologi } \\
\hline Serosum-endometrioid & 14 & 1,253 & 0,535 \\
\hline Musinosum-clear cell & 17 & & \\
\hline Lain-lain & 13 & & \\
\hline \multicolumn{4}{|l|}{ Operasi sitoreduksi } \\
\hline Optimal & 17 & 3,964 & $0,046^{*}$ \\
\hline Suboptimal & 13 & & \\
\hline
\end{tabular}

Hasil penelitian ini menunjukkan tidak adanya perbedaan yang bermakna antara rejimen Paclitaxel-Carboplatin dengan rejimen CAP dalam hal complete response. Dalam uji bivariat dengan variabel luar didapatkan bahwa stadium dan jenis operasi sitoreduksi merupakan faktor independen yang mempengaruhi tercapainya complete response. Hal ini sesuai dengan teori bahwa faktor utama yang mempengaruhi prognosis kanker ovarium adalah stadium penyakit, residu tumor, dan derajat diferensiasi sel tumor. ${ }^{7}$ Meski data dalam penelitian ini tidak homogen oleh karena sifat penelitian yang observasional, namun dalam uji multivariat terhadap faktor-faktor luar yang mungkin berpengaruh, hanya didapatkan jenis operasi sitoreduksi yang secara statistik bermakna mempengaruhi variabel bebas dan complete 
response yang dicapai. Selain itu dalam analisis pengaruh faktor luar terhadap progressionfree survival didapatkan kelompok pasien yang menjalani operasi sitoreduksi optimal memiliki PFS yang lebih panjang (17 bulan) dibandingkan kelompok suboptimal (13 bulan) (p log-rank=0,046). Korelasi klinis dari hal tersebut adalah bahwa operasi sitoreduksi maksimal masih menjadi determinan paling kuat bagi prognosis yang lebih baik pada penderita kanker ovarium epitelial stadium III dan IV di era platinum seperti saat ini. ${ }^{9,10}$ Oleh karena itu, rujukan kepada ahli onkologi untuk menjalani operasi primer merupakan tindakan terbaik jika mencurigai penderita dengan kanker ovarium stadium lanjut. ${ }^{9}$

Sementara itu, dari analisis kurva KaplanMeier didapatkan median progression-free survival kelompok Paclitaxel-Carboplatin tidak menunjukkan perbedaan bermakna dengan PFS kelompok CAP (15 bulan dan 14 bulan, log-rank test $\mathrm{p}=0,741)$. Hal-hal tersebut di atas berbeda dengan penelitian lain (GOG \#111 dan OV10) yang menunjukkan bahwa penambahan Paclitaxel dalam kombinasi kemoterapi memberikan complete response hampir dua kali lipat lebih banyak dan PFS yang lebih panjang. ${ }^{8,11}$ Hasil dari penelitian ini lebih identik dengan ICON3 yang menyatakan bahwa PFS pada kelompok Paclitaxel-Carboplatin tidak berbeda bermakna dengan PFS kelompok kontrol (CAP/Carboplatin tunggal). Hal tersebut terjadi karena adanya perbedaan terapi dalam kelompok kontrol, dimana kombinasi Cyclophosphamide $750 \mathrm{mg} /$ $\mathrm{m}^{2}$-Cisplatin $75 \mathrm{mg} / \mathrm{m}^{2}$ sebagai kontrol pada penelitian GOG \#111 dan OV10 tampaknya lebih inferior dibandingkan kelompok kontrol ICON3 yang menggunakan CyclophosphamideAdriamycin-Cisplatin. ${ }^{6,12}$ Secara tidak langsung hal ini diperkuat oleh Ovarian Cancer MetaAnalysis Project ${ }^{13}$ yang menyatakan bahwa rejimen CAP lebih superior dibandingkan rejimen $\mathrm{CP}$ dalam hal survival (HR $0,85,95 \% \mathrm{Cl}$ $0,75-0,98, p=0,02)$. CAP juga digunakan dalam penelitian ini, namun dosis Paclitaxel yang digunakan adalah $135 \mathrm{mg} / \mathrm{m}^{2}$ (infus $3 \mathrm{jam}$ ) dan Carboplatin $400 \mathrm{mg} / \mathrm{m}^{2}$, berbeda dengan ICON3 yang menggunakan Paclitaxel $175 \mathrm{mg} / \mathrm{m}^{2}$ (infus 3 jam) dan Carboplatin yang dihitung berdasarkan rumus Calvert $5(G F R+25)$ mg. Namun, meski menunjukkan hasil yang identik dalam hal progression-free survival, ICON3 memasukkan penyakit dengan stadium I-IV menurut kriteria FIGO ke dalam sampel, sementara penelitian ini hanya mengikutsertakan kanker ovarium stadium lanjut (stadium III-IV FIGO). Oleh karena itu masih belum dapat diambil kesimpulan mengenai keefektifan rejimen Paclitaxel-Carboplatin dibandingkan dengan CAP pada kanker ovarium epitelial stadium lanjut berdasarkan penelitian ICON3.

Hal lain yang didapat dari penelitian ini adalah kurva Kaplan-Meier yang menggambarkan progression-free survival kelompok PaclitaxelCarboplatin tampak memiliki pola berbeda dengan kelompok CAP, karena bagian dasar kurva menunjukkan interval yang lebih panjang. Perbedaan ini belum dapat menyimpulkan bahwa Paclitaxel-Carboplatin lebih baik dibandingkan dengan CAP oleh karena pengaruh beberapa faktor luar, yaitu derajat diferensiasi sel tumor dan performance status, belum dapat dianalisis akibat data yang tidak lengkap. Selain itu, jumlah sampel penelitian yang relatif sedikit juga berpengaruh terhadap heterogeneitas kelompok sampel.

Jadi dapat disimpulkan bahwa rejimen Paclitaxel-Carboplatin yang digunakan sebagai kemoterapi lini pertama di RSUP Dr.Sardjito tidak lebih superior jika dibandingkan dengan CAP dalam hal complete response dan PFS, dimana jenis operasi sitoreduksi merupakan faktor independen yang mempengaruhi complete response dan PFS pada penderita kanker ovarium 
epitelial stadium lanjut. Meski demikian, masih diperlukan penelitian lebih lanjut dengan datadata yang lebih lengkap berkaitan dengan derajat diferensiasi, profil toksisitas masing-masing rejimen, kualitas hidup pasca-kemoterapi, dan pengukuran overall survival (sebagai gold standard keefektifan kemoterapi) ${ }^{14}$ di kemudian hari untuk mengetahui keunggulan kedua kelompok kemoterapi tersebut. Pertimbangan lain dalam menentukan pilihan kemoterapi adalah cost benefit. Dari sudut pandang cost benefit kombinasi CAP lebih murah dibandingkan dengan Paclitaxel-Carboplatin, meski pada akhirnya pertimbangan mengenai biaya tidak boleh melampaui pertimbangan efikasi dari rejimen kemoterapi itu sendiri.

\section{KESIMPULAN DAN SARAN}

Perlu dilakukan penelitian lebih lanjut dengan sampel yang lebih banyak dan data yang lebih lengkap untuk mengukur survival, profil toksisitas, dan kualitas hidup guna menentukan keunggulan rejimen Paclitaxel-Carboplatin dibandingkan dengan CAP sebagai kemoterapi lini pertama pada penderita kanker ovarium stadium lanjut. Dan dalam penentuan pilihan rejimen kemoterapi harus dipertimbangkan pula profil toksisitas dan kualitas hidup yang dicapai apabila ternyata diketahui memiliki efikasi yang sama dengan rejimen lain.

\section{DAFTAR PUSTAKA}

1. Berek JS. Berek\&Novak's Gynecology. Chapter 35: Ovarian and Fallopian Tube Cancer. 14th ed. Lippincott Williams \& Wilkins. Philadelphia. 2007. p. 1457-1504.

2. Kikkawa F, Nawa A, Ino K, Shibata K, Kajiyama $\mathrm{H}$, Nomura S. Advances in Treatment of Epitelial Ovarian Cancer. 2006. vol. 68, p. 19-26.

3. Bookman MA, Brady MF, McGuire WP, Harper PG, Alberts DS, Friedlander M, Colombo N, Fowler JM, Argenta PA, De Geest K, Mutch DG, Burger RA Swart AM, Trimble EL, Accario-Winslow C, Roth
LM . Evaluation of New Platinum-Based Treatment Regimens in Advanced-Stage Ovarian Cancer: A Phase III Trial of the Gynecologic Cancer InterGroup. J Clin Oncol. 2009. vol. 27. p. 1419-1425.

4. Meerpohl HG, Pfleiderer A, Kleine W, Teufel G. Chemotherapy for stage III-IV ovarian cancer: the CAP-regimen in previously untreated patients. Onkologie. 1982. vol. 5, p. 238-241.

5. Colombo N, Parma G, Bocciolone L, Franchi D, Sideri M, Maggioni A. Medical therapy of advanced malignant epitelial tumours of the ovary. Forum (Genova). 2000. vol. 4. p. 323-32.

6. ICON3: International Collaborative Ovarian Neoplasm Group. Paclitaxel plus carboplatin versus standard chemotherapy with either single-agent carboplatin or cyclophosphamide, doxorubicin, and cisplatin in women with ovarian cancer randomised trial. The Lancet. 2002. vol. 360. no. 9332. p. 505515.

7. Di Saia PJ, Creasman WT, Mannel RS, McMeekin DS, Mutch DG. Epitelial Ovarian Cancer and Basic Principles of Chemotherapy in Cinical Gynecology Oncology. $8^{\text {th }}$ ed. 2012. Saunders, Philadelphia. p. 285-258, 515-538.

8. McGuire WP, Hoskins WJ, Brady MF, Kucera PR, Partridge EE, Look KY, Clarke-Pearson DL, Davidson M. Cyclophosphamide and cisplatin compared with paclitaxel and cisplatin in patients with stage III and stage IV ovarian cancer. N Engl J Med. 1996. vol. 334. p. 1-6.

9. Bristow RE, Tomacruz RS, Armstrong DK, Trimble EL, Montz FJ. Survival Effect of Maximal Cytoreductive Surgery for Advanced Ovarian Carcinoma During the Platinum Era: A Meta-Analysis. J Clin Oncol. 2002. vol. 2. p. $1248-1259$.

10. Wimberger $P$, Wehling $M$, Lehmann $N$, Kimmig $R$, Schmalfeldt B, Burges A, Harter P, Pfisterer J, du Bois $A$. Influence of residual tumor on outcome in ovarian cancer patients with FIGO stage IV disease: an exploratory analysis of the AGO-OVAR (Arbeitsgemeinschaft Gynaekologische Onkologie Ovarian Cancer Study Group). Ann Surg Oncol. 2010. vol. 17. no. 6. p. 642-648.

11. Piccart MJ, Bertelsen K, James K, Cassidy J, Mangioni C, Simonsen E, Stuart G, Kaye S, Vergote I, Blom R, Grimshaw R, Atkinson RJ, Swenerton KD, Trope C, Nardi M, Kaern J, Tumolo S, Timmers P, Roy 
JA, Lhoas $F$, Lindvall $B$, Bacon $M$, Birt A, Andersen JE, Zee B, Paul J, Baron B, Pecorelli S. Randomized Intergroup Trial of Cisplatin-Paclitaxel Versus Cisplatin-Cyclophosphamide in Women With Advanced Epitelial Ovarian Cancer: Three-Year Results, Journal of the National Cancer Institute. 2000. Vol. 92. No. 9. p. 699-708.

12. Sandercock J, Parmar MKB, Torri V, Qian W. First-line treatment for advanced ovarian cancer : paclitaxel, platinum and the evidence, British Journal of Cancer. 2002. vol. 87. p. $815-824$.

13. Ovarian Cancer Meta-Analysis Project. Cyclophosphamide plus cisplatin versus cyclophosphamide, doxorubicin, and cisplatin chemotherapy of ovarian carcinoma: a meta-analysis. Journal of Clinical Oncology. 1991. vol. 9. no. 9. p. 1668-1674.

14. Oza AM, Castonguay V, Tsoref D, Diaz-Padilla I, Karakasis K, Mackay H, Welch S, Weberpals J, Hoskins $P$, Plante $M$, Provencher $D$, Tonkin $K$, Covens A, Ghatage P, Gregoire J, Hirte H, Miller D, Rosen B, Maroun J, Buyse M, Coens C, Brady MF, Stuart GCE. Progression-free survival in advanced ovarian cancer: a Canadian review and expert panel perspective, Current Oncology. 2011. vol. 18. suppl.2. p. 20-27. 